\title{
EVALUASI SISTEM AKUNTANSI DALAM RANGKA MENINGKATKAN KINERJA PEGAWAI BADAN PENGELOLA KEUANGAN DAN ASET DAERAH PROVINSI BALI
}

\author{
Siska Tilly Elisabeth Lumbantobing \\ Badan Perencanaan Dan Pembangunan Daerah Provinsi Bali; \\ email : siskatobing07@gmail.com
}

\begin{abstract}
The objective of this research to reveal (1) the accounting system in the Regional Financial and Asset Management Agency of the Bali Province; (2) obstacles faced to improve the understanding of the accounting system of the Regional Financial and Asset Management Agency of the Bali Province; and (3) evaluation to overcome obstacles to improve the understanding of the accounting system of the Regional Financial and Asset Management Agency of the Bali Province in order to improve its performance. The method used in this research is descriptive qualitative. The research result indicated (1) The accounting system in the Regional Asset Financial Management Agency of the Bali Province is a system or Regional Government Accounting Standards (SAPD) based on IT systems. This system benefits the improvement of the quality of financial reporting in the Bali Province; (2) Obstacles faced to improve the understanding of the accounting system of the Provincial Asset Financial Management Agency employees are obstacles that arise from changes in laws and regulations, the form of financial statements that were previously only four plus three types of new reports, accrual-based budgeting, recording of revenue recognition and recording of expenditure/expense recognition and the resistance of employees who reject the changes; and (3) Evaluation to find out the obstacles to improve accounting understanding is expected so that the performance of employees can improve including evaluating the constraints of changes in legislation carried out more intense socialization, evaluation of constraints on the types of financial statements should be the type of financial report set in the form of certainty, evaluation of constraints related to accrual-based budgeting, recording of revenue recognition and recording of expenditure / expense recognition must be carried out according to the demands of the new legislation. Further evaluation of the constraints of employee resistance is carried out by giving a correct understanding of changes in legislation.
\end{abstract}

Keywords: Evaluation, System, Accounting, Employee Understanding, Performance.

\begin{tabular}{l}
\hline Abstrak \\
\hline Tujuan penelitian ini untuk mengetahui (1) sistem akuntansi pada Badan Pengelola Keuangan dan Aset \\
Daerah Provinsi Bali; (2) kendala-kendala yang dihadapi untuk meningkatkan pemahaman sistem akuntansi \\
Pegawai Badan Pengelola Keuangan dan Aset Daerah Provinsi Bali; dan (3) evaluasi untuk mengatasi \\
kendala-kendala untuk meningkatkan pemahaman sistem akuntansi Pegawai Badan Pengelola Keuangan \\
dan Aset Daerah Provinsi Bali dalam rangka meningkatkan kinerjanya. Metode penelitian yang digunakan \\
\hline
\end{tabular}


dalam penelitian ini bersifat deskriptif kualitatif. Hasil penelitian menunjukkan (1) Sistem akuntansi pada Badan Pengelola Keuangan Aset Daerah Provinsi Bali adalah sistem atau Standar Akuntansi Pemerintahan Daerah (SAPD) yang berbasis IT system. Sistem ini memberi manfaat pada peningkatan kualitas pelaporan keuangan di Provinsi Bali; (2) Kendala-kendala yang dihadapi untuk meningkatkan pemahaman sistem akuntansi pegawai Badan Pengelola Keuangan Aset Daerah Provinsi merupakan kendala yang berasal dari adanya perubahan peraturan perundang-undangan, jenis laporan keuangan yang tadinya hanya empat ditambah dengan tiga jenis laporan baru, anggaran berbasis akrual, pencatatan pengakuan pendapatan dan pencatatan pengakuan belanja/beban serta masih adanya resistensi pegawai yang menolak perubahan; dan (3) Evaluasi untuk mengetahui kendala-kendala untuk meningkatkan pemahaman akuntansi yang diharapkan agar kinerja pegawai dapat ditingkatkan meliputi sosialisasi yang lebih intens, sebaiknya jenis laporan keuangan ditetapkan saja berupa jenisnya agar terjadi kepastian, anggaran berbasis akrual, pencatatan pengakuan pendapatan dan pencatatan pengakuan belanja/beban harus dilakukan sesuai tuntutan peraturan perundang-undangan yang baru dan memberi pemahaman yang benar atas perubahan peraturan perundang-undangan..

Kata Kunci: Evaluasi, Sistem, Akuntansi, Pemahaman Pegawai, Kinerja.

\section{PENDAhUluan}

\subsection{Latar Belakang Masalah}

Penerapan sistem akuntansi dalam pengelolaan keuangan daerah berfungsi sebagai mekanisme, prosedur kerja dan alat kontrol dalam pengelolaan keuangan. Agar semua pelaksana keuangan daerah mampu mengelola keuangan harus memahami sistem akuntansi, oleh sebab itu pemahaman pengelola keuangan mengenai sistem akuntansi keuangan daerah merupakan faktor penting yang harus diperhatikan. Hal ini akan menunjang pengelola keuangan daerah dalam menyajikan laporan keuangan daerah. Sistem Akuntansi Keuangan Daerah yaitu serangkaian prosedur mulai dari proses pengumpulan data, pencatatan, pengikhtisaran, sampai dengan pelaporan keuangan, dalam rangka pertanggung jawaban pelaksanaan APBD yang dapat dilakukan secara manual atau menggunakan aplikasi komputer (Peraturan Menteri Dalam Negeri Nomor 59 Tahun 2007 tentang Perubahan Atas Peraturan Menteri Dalam Negeri Nomor 13 Tahun 2006 tentang Pedoman Pengelolaan Keuangan Daerah). Dengan adanya sistem akuntansi keuangan daerah tersebut maka kemungkinan untuk menghasilkan laporan keuangan yang berkualitas cukup tinggi.

Untuk mengatur lebih lanjut mengenai Standar Akuntansi Pemerintahan, maka diterbitkan Peraturan Pemerintah Nomor 71 Tahun 2010 tentang Standar Akuntansi Pemerintahan. Sebagai peraturan pelaksanaannya pada tahun 2013 diterbitkan Peraturan Menteri Dalam Negeri Nomor 64 Tahun 2013 tentang Penerapan Sistem Akutansi Pemerintah Berbasis Akrual pada Pemerintahan Daerah. Untuk lingkup Provinsi Bali, penggunaan Standar Akuntansi Pemerintah diatur dalam Peraturan Daerah Provinsi Bali Nomor 8 Tahun 2014 tentang Pokok-Pokok Pengelolaan Keuangan Daerah yang kemudian ditindaklanjuti dengan Peraturan Gubernur Bali Nomor 101 Tahun 2015 tentang Kebijakan 
Akuntansi Provinsi Bali. Pergub Bali No. 101 Tahun 2015 mengamanatkan penggunaan Sistem Akutansi/Sistem Akutansi Pemerintah Daerah (SAPD) pada SKPD-SKPD di Provinsi Bali.

Bagi Pemerintah Daerah, keuangan merupakan masalah penting baginya dalam mengatur, mengurus rumah tangga daerah. Pentingnya keuangan dan pengelolaan keuangan daerah, Wajong (2015: 81) mengatakan bahwa “(1) Pengendalian keuangan mempunyai dampak yang begitu besar kemudian hari; (2) Kepandaian mengendalikan daerah tidak akan memberikan hasil yang memuaskan dan abadi tanpa cara pengendalian keuangan yang baik; (3) Anggaran adalah alat utama dalam pengendalian keuangan daerah".Pemahaman pegawai Badan Pengelola Keuangan dan Aset Daerah Provinsi Bali terhadap sistem akuntansi menjadi indikator bahwa seorang pegawai memiliki kemampuan untuk melaksanakan tugas-tugasnya. Semakin tinggi pemahaman terhadap sistem akuntansi, pegawai tersebut dan semakin memahami apa yang menjadi tugas dan tanggung jawab yang diberikan kepada pegawai tersebut. Hal ini berarti pemahaman yang baik dari sistem akuntansi anggaaran dapat meningkatkan kinerja pegawai yang bersangkutan.

Kondisi tersebut di atas menunjukkan bahwa sistem akuntansi memang tidak mudah untuk dipahami oleh pegawai (SDM). Padahal pegawai di Badan Pengelola Keuangan dan Aset Daerah Provinsi Bali mutlak harus memahami sistem akuntansi agar dapat melaporkan pengelolaan keuangan dan aset daerah. Pegawai-pegawai yang kurang memahami sistem akuntansi menunjukkan kinerja yang rendah. Hal ini merupakan sumber masalah apakah sistem akuntansi memang terlalu rumit untuk dipahami oleh pegawai-pegawai tersebut.Sistem akuntansi memang tidak mudah untuk dipahami oleh pegawai (SDM). Padahal pegawai di Badan Pengelola Keuangan dan Aset Daerah Provinsi Bali mutlak harus memahami sistem akuntansi agar dapat melaporkan pengelolaan keuangan dan aset daerah. Pegawai-pegawai yang kurang memahami sistem akuntansi menunjukkan kinerja yang rendah. Hal ini merupakan sumber masalah apakah sistem akuntansi memang terlalu rumit untuk dipahami oleh pegawai-pegawai tersebut. Beberapa hal yang diidentifikasi sebagai masalah terkait belum optimalnya pemahaman pegawai Badan Pengelola Keuangan dan Aset Daerah Provinsi Bali terhadap sistem akuntansi sehingga menyebabkan masih ada kinerja yang rendah adalah:

1. Masih ada pegawai pada Badan Pengelola Keuangan dan Aset Daerah Provinsi Bali yang kurang memahami sistem akuntansi.

2. Masih ada pegawai pada Badan Pengelola Keuangan dan Aset Daerah Provinsi Bali yang memiliki sistem akutansi yang digunakan terlalu rumit sehingga perlu dievaluasi. 
3. Pegawai Badan Pengelola Keuangan dan Aset Daerah yang kurang memahami atau tidak mengerti sistem akuntansi, kinerjannya rendah.

\subsection{Rumusan Masalah}

Berdasarkan latar belakang masalah yang telah di uraikan di atas, maka rumusan masalah dalam penelitian ini adalah:

1. Bagaimanakah sistem akuntansi pada Badan Pengelola Keuangan dan Aset Daerah Provinsi Bali?

2. Kendala-kendala apa saja yang dihadapi untuk meningkatkan pemahaman sistem akuntansi pegawai Badan Pengelola Keuangan dan Aset Daerah Provinsi Bali?

3. Bagaimana evaluasi untuk mengatasi kendala-kendala untuk meningkatkan pemahaman sistem akuntansi Pegawai Badan Pengelola Keuangan dan Aset Daerah Provinsi Bali dalam rangka meningkatkan kinerjanya?

\section{METODE PENELITIAN}

Metode penelitian yang digunakan dalam penelitian ini bersifat deskriptif kualitatif. Pengumpulan data yang digunakan, sebagaimana lazim dalam penelitian kualitatif adalah observasi, wawancara dan dokumentasi. Data yang terkumpul dianalisis dengan model interaktif dari Miles dan Huberman.

\section{HASIL DAN PEMBAHASAN}

\subsection{Sistem Akuntansi pada Badan Pengelola Keuangan Aset Daerah Provinsi Bali}

Hasil penelitian menunjukkan bahwa Badan Pengelola Keuangan dan Aset Daerah Provinsi Bali menggunakan Sistem Akuntansi yang disebut dengan istilah Standar Akuntansi Pemerintahan Daerah (SAPD). Hasil penelitian ini sesuai dengan teori yang dikemukakan oleh Wijaya (2014: 81) yang menyatakan bahwa seluruh pemerintahan di Indonesia baik pemerintahan pusat maupun pemerintahan daerah menggunakan sistem atau Standar Akuntansi Pemerintah (SAP) untuk Pemerintah Pusat dan sistem atau Standar Akuntansi Pemerintahan Daerah (SAPD) untuk Pemerintah Daerah. SAP dan SAPD menurut Wijaya (2014: 86), Standar Akuntansi Pemerintahan (SAP) merupakan standar akuntansi pertama di Indonesia yang mengatur mengenai akuntansi pemerintahan Indonesia. Sehingga dengan adanya standar ini, maka laporan keuangan pemerintah yang merupakan hasil dari proses akuntansi diharapkan dapat digunakan sebagai alat komunikasi antara pemerintah dengan stakeholders sehingga tercipta pengelolaan keuangan negara yang transparan dan akuntabel. 
Hasil penelitian juga sesuai dengan peraturan perundang-undangan yaitu dalam lingkup nasional Peraturan Pemerintah Nomor 71 Tahun 2010 dan Peraturan Menteri Dalam Negeri Nomor 64 Tahun 2013 yang mengatur bahwa standar akuntansi pemerintahan, standar akuntansi pemerintahan yang selanjutnya disingkat SAP, adalah prinsip-prinsip akuntansi yang diterapkan dalam menyusun dan menyajikan laporan keuangan pemerintah. Dapat disimpulkan bahwa SAP merupakan persyaratan yang mempunyai kekuatan hukum dalam upaya meningkatkan kualitas laporan keuangan pemerintah di Indonesia. Untuk Pemerintahan Daerah SAP tersebut disebut SAPD. Untuk lingkup Bali SAPD ini diatur dalam Peraturan Daerah Provinsi Bali No. 8 Tahun 2014 dan Peraturan Gubernur Bali No. 101 Tahun 2015. Dalam perjalanannya Pergub Bali No. 101 Tahun 2015 ini diubah dengan Pergub Bali No. 96 Tahun 2018. Maksudnya diubah disini adalah merubah bagian-bagian tertentu dari Pergub Bali No. 101 Tahun 2015 dan Pergub Bali No. 96 Tahun 2018 bukan menggantikan Pergub Bali No. 101 Tahun 2018. Jadi, Pergub Bali No. 96 Tahun 2018 bukan menggantikan Pergub Bali No. 101 Tahun 2015, kedua Pergub ini saling melengkapi.

Selanjutnya pembahasan tentang penelitian SAPD ini ditinjau dari manfaat SAPD, komitmen dari pimpinan, SAPD berbasi IT System dan tersedianya Sumber Daya Manusia (SDM) yang kompeten, yang diuraikan sebagai berikut:

a. Manfaat SAPD.

Penerapan SAPD di Provinsi Bali pada umumnya dan Badan Pengelola Keuangan dan Aset Daerah Provinsi Bali pada khususnya diyakini akan berdampak pada peningkatan kualitas pelaporan keuangan di Provinsi Bali. Hal ini berarti informasi keuangan pemerintahan akan dapat menjadi dasar pengambilan keputusan di Provinsi Bali dan juga terwujudnya transparansi, serta akuntabilitas.

b. Komitmen dari Pimpinan.

Sebagaimana telah dikemukakan dalam hasil penelitian bahwa penggunaan SAPD pada Badan Pengelola Keuangan dan Aset Daerah Provinsi Bali, tidak hanya membutuhkan komitmen dari pimpinan Badan Pengelola Keuangan dan Aset Daerah Provinsi Bali saja, tapi juga dari Gubernur Bali. Gubernur Bali sendiri telah memberikan komitmennya dengan menerbitkan Peraturan Daerah Provinsi Bali Nomor 8 Tahun 2014 tentang Pokok-Pokok Pengelolaan Keuangan Daerah dan Peraturan Gubernur Bali Nomor 101 Tahun 2015 tentang Kebijakan Akuntansi Provinsi Bali. Dalam perjalanannya Peraturan Gubernur Bali No. 101 Tahun 2015 tersebut diubah dengan Peraturan Gubernur Bali No. 96 Tahun 2018 tentang Perubahan Atas Peraturan Gubernur Bali No. 101 Tahun 2015 tentang Kebijakan Akuntansi Pemerintahan Provinsi Bali. Hasil penelitian tersebut 
mendukung teori Sinaga (2015: 45) yang menyebutkan setiap perubahan membutuhkan dukungan penuh oleh pimpinan suatu institusi. Hal ini merupakan kunci keberhasilan atas perubahan tersebut. Komitmen yang kuat akan mendorong implementasi secara menyeluruh perubahan basis akuntansi yang memang tidak mudah. Salah satu penyebab kelemahan penyusunan laporan keuangan pada beberapa kementerian/lembaga adalah lemahnya komitmen pimpinan satuan kerja khususnya SKPD-SKPD dan badan-badan pada Pemerintahan Daerah.

c. SAPD Berbasi IT System.

Hasil penelitian menunjukkan bahwa SAPD sifatnya kompleks sehingga membutuhkan sistem yang terpadu dan didukung oleh teknologi informasi yang memadai. Hal ini tentu saja membutuhkan biaya dan waktu yang tidak sedikit untuk dapat mewujudkannya. Ketidaksiapan sistem akan menyebabkan kegagalan dalam implementasi sistem akuntansi pemerintahan yang baru dengan basis akrual. Selain itu, perlu juga dibangun sistem pengendalian intern yang memadai untuk memberikan keyakinan memadai atas tercapainya tujuan organisasi melalui kegiatan yang efektif dan efisien, keandalan pelaporan keuangan, pengamanan aset negara, dan ketaatan terhadap peraturan perundang-undangan.

d. Tersedianya Sumber Daya Manusia (SDM) yang Kompeten.

Hasil penelitian meningkatkan bahwa Badan Pengelola Keuangan dan Aset Daerah Provinsi Bali bertanggungjawab atas laporan keuangan. Penyiapan dan penyusunan laporan keuangan tersebut memerlukan SDM dalam Badan Pengelola Keuangan dan Aset Daerah Provinsi Bali yang menguasai akuntansi pemerintahan. Di Badan Pengelola Keuangan dan Aset Daerah Provinsi Bali diperlukan SDM yang memiliki kompetensi tinggi tidak saja di bidang akuntansi, namun terlebih-lebih di bidang IT.Penyusunan laporan keuangan yang lebih kompleks dengan batasan waktu yang ditentukan oleh peraturan perundang-undangan tentu saja membutuhkan individu-individu yang memiliki keterampilan dan pengalaman yang memadai. Namun pada kenyatannya, jumlah sumber daya manusia yang dapat memenuhi tuntutan tersebut masih belum mencukupi. Hal ini menjadi tantangan yang harus diatasi agar penerapan sistem akuntansi pemerintahan berbasis akrual dapat dilaksanakan sesuai ketentuan yang berlaku (Widjajarso, 2014: 36)

Berdasarkan pembahasan yang telah dikemukakan di atas maka dapat disimpulkan bahwa sistem akuntansi pada Badan Pengelola Keuangan Aset Daerah Provinsi Bali adalah sistem atau Standar Akuntansi Pemerintahan Daerah (SAPD) yang berbasis IT system. 
Sistem ini memberi manfaat pada peningkatan kualitas pelaporan keuangan di Provinsi Bali. Untuk menggunakan sistem tersebut diperlukan komitmen tidak hanya dari pimpinan Badan Pengelola Keuangan dan Aset Daerah Provinsi Bali saja, tapi juga dari Gubernur Bali. (SAPD) yang digunakan ini berbasis IT system sehingga diperlukan SDM yang memiliki kompetensi tinggi tidak saja di bidang akuntansi, namun terlebih-lebih di bidang IT.

\subsection{Kendala-Kendala yang Dihadapi untuk Meningkatkan Pemahaman Sistem Akuntansi Pegawai Badan Pengelola Keuangan Aset Daerah Provinsi Bali}

a. Kendala dari Peraturan Perundang-Undangan.

Hasil penelitian menunjukkan bahwa kendala dari peraturan perundang-undangan adalah dengan terbitnya Pergub Provinsi Bali No. 96 Tahun 2018 yang merubah Pergub Provinsi Bali No. 101 Tahun 2015, pemahaman pegawai Badan Pengelola Keuangan dan Aset Daerah Provinsi Bali terkait dengan perubahan tersebut harus di-restart dengan jalan sosialisasi terhadap perubahan-perubahan yang terkandung pada Pergub Provinsi Bali No. 96 Tahun 2018.Penerapan SAP/SAPD berbasis akrual dilakukan hanya sebagai wujud kepatuhan kepada peraturan, seolah-olah hanya sekedar mengikuti format dan alur hanya sekedar untuk menggugurkan kewajiban. Hal ini merupakan hal yang akan dilihat pada sektor publik, bahwa setiap ada perubahan peraturan maka pemerintah daerah yang dikoordinasi oleh pemerintah pusat wajib melaksanakan peraturan baru tersebut karena adanya nilai kepatuhan terhadap hukum. Nilai kepatuhan terhadap hukum tersebut mendorong tindakan pemerintah Kota Makassar untuk senantiasa mengikuti aturan main dari SAP/SAPD yang berlaku saat ini yaitu SAP berbasis akrual.

b. Kendala dari Jenis Laporan Keuangan yang Ditetapkan.

Hasil penelitian menunjukkan kendala lain yang dihadapi adalah adanya perubahan jenis laporan keuangan yang harus dibuat. Misalnya saja jika sebelumnya hanya empat laporan keuangan yakni laporan realisasi anggaran, neraca, laporan arus kas dan catatan atas laporan keuangan. Namun ada jenis laporan tambahan selain yang dipersyaratkan oleh peraturan perundangan dengan menambahkan tiga jenis laporan baru yaitu laporan perubahan saldo anggaran lebih, laporan operasional dan laporan perubahan ekuitas. Hasil penelitian ini sesuai dengan teori Widjajarso (2014: 38) yang menyebutkan secara peraturan undangundang keuangan negara dan undang-undang perbendaharaan, memang hanya mensyaratkan adanya empat laporan keuangan yakni laporan realisasi anggaran, neraca, laporan arus kas dan catatan atas laporan keuangan. Di satu pihak, KSAP saat ini telah mengantisipasi jenis laporan tambahan selain yang dipersyaratkan oleh peraturan 
perundangan dengan menambahkan tiga jenis laporan baru yaitu laporan perubahan saldo anggaran lebih, laporan operasional dan laporan perubahan ekuitas, seperti tercantum dalam konsep publikasi standar akuntansi pemerintahan berbasis akrual. Di lain pihak, penyusun laporan baik pemerintah pusat maupun pemerintah daerah sepertinya masih menunggu hasil KSAP, meskipun sudah terlihat aktif dalam berbagai forum seperti limited hearing dan diskusi-diskusi basis akrual.

c. Kendala dari Anggaran Berbasis Akrual yang Ditetapkan.

Hasil penelitian menunjukkan akuntansi berbasis akrual hampir selalu diiringi dengan penganggaran berbasis akrual. Namun, pada kenyataannya penerapan basis akrual tidak harus diikuti dengan penerapan anggaran berbasis akrual.

d. Kendala dari Pengakuan Pendapatan.

Berdasarkan hasil penelitian diketahui bahwa pada sistem akuntansi basis akrual, pendapatan diakui saat timbul hak dari pemerintah. Hal ini bertentangan dengan sistem pemungutan pajak yang menganut sistem self assesment yang masih memungkinkan pendapatan tersebut bisa saja berubah karena adanya restitusi pajak, sehingga bisa saja pendapatan yang telah diakui tersebut berubah. Hasil penelitian ini sesuai dengan teori dari Fakhrurazi (2014: 62) yang menyebutkan pendapatan harus diakui jika telah muncul hak sehingga pencatatan pendapatan dilakukan setiap kali ada transaksi munculnya hak tersebut. Standar akuntansi pemerintah nantinya harus menciptakan kriteria yang jelas atas pengakuan pendapatan tersebut. Dengan demikian, pendapatan pajak yang harus diakui adalah jika dapat diukur dan tersedia untuk operasi entitas pelaporan. Contoh jenis pajak yang memenuhi kriteria seperti itu adalah pajak properti, misalnya pajak bumi bangunan, pajak kendaraan bermotor dan sebagainya. Dalam kondisi itu, pajak properti harus langsung diakui dan dicatat sebagai pendapatan. Untuk jenis pajak yang lain, misalnya pajak penghasilan, kriteria dapat diukur dan tersedia tetap harus diberlakukan. Jika kedua kriteria tersebut tidak secara bersamaan dapat terpenuhi, pendapatan pajak jenis itu tidak dapat diakui sebagai pendapatan. Alternatifnya, karena pendapatan pajak mempunyai karakteristik non exchange revenues, peraturan perpajakan harus ditafsirkan oleh badan penyusun standar akuntansi pemerintahan kapan memenuhi kriteria measurable dan kapan memenuhi available.

e. Kendala dari Pengakuan Belanja/Beban.

Hasil penelitian menunjukkan istilah belanja tidak dikenal dalam sistem akuntansi berbasis akrual. Dalam sistem akuntansi berbasis akrual istilah belanja diganti dengan istilah beban atau biaya. Namun dalam banyak hal, Pemprov Bali masih menggunakan 
istilah belanja ini.Hasil penelitian ini sesuai dengan teori Fakhrurazi (2014: 66) yang menyatakan untuk laporan realisasi anggaran dan laporan perubahan saldo anggaran lebih, terminologi belanja sudah tepat dan hal ini juga sesuai dengan peraturan perundangan yang berkaitan dengan anggaran pendapatan dan belanja negara. Sedangkan untuk laporan lain, yakni, laporan operasional dan laporan perubahan ekuitas, terminologi beban atau biaya harus menggantikan terminologi belanja. Dengan demikian, biaya non kas seperti biaya depresiasi akan tercantum dalam laporan operasional, laporan perubahan ekuitas dan neraca, karena tidak ada arus kas keluar seperti pada belanja. Keberhasilan perubahan akuntansi pemerintahan sehingga dapat menghasilkan laporan keuangan yang lebih transparan dan lebih akuntabel memerlukan upaya dan kerja sama dari berbagai pihak. Untuk itu perlu diidentifikasi tantangan yang mungkin menghambat implementasi akuntansi pemerintahan dan membangun strategi untuk implementasi.

f. Kendala dari Resistensi Pegawai.

Hasil penelitian terkait dengan kendala resistensi pegawai menunjukkan ada pegawai yang menunjukkan sikap resistensi karena pegawai ini sudah terbiasa dengan sistem yang lama. Resistensi ini dicoba untuk ditularkan pada pegawai yang menerima perubahan. Hal inilah yang menjadi kendala bagi berhasilnya perubahan.Hasil penelitian ini mendukung teori dari Satmoko (2010: 6-9), kendala penerapan standar akuntansi pemerintahan berbasis akrual yaitu sebagai berikut: pertama, kompleksitas laporan keuangan. Laporan yang harus disiapkan oleh pemerintah menjadi bertambah yaitu enam laporan dan satu CALK tanpa membedakan laporan pokok dan laporan pendukung. Hal tersebut dapat berdampak pada perubahan sistem akuntansi pemerintah yang pada akhirnya akan membuat alokasi anggaran menjadi cukup besar. Kedua, kondisi pemerintah. Kondisi pemerintah meliputi sumber daya manusia dan infrastruktur untuk menerapkan SAP berbasis akrual serta kualitas laporan keuangan pemerintahan. Hal tersebut dibuktikan dengan masih banyaknya laporan keuangan yang mendapat opini disclaimer dari Badan Pemeriksa Keuangan. Ketiga, dampak penerapan SAP berbasis akrual. Penerapan SAP berbasis akrual dapat berdampak pada jangka waktu penyelesaian dan penyampaian laporan keuangan, serta dapat berpengaruh pada jangka waktu pemeriksaan BPK RI mengingat laporan yang harus disiapkan lebih banyak dibandingkan dengan SAP sebelumnya. Keempat, kondisi pengendalian internal pemerintah yang belum memadai.

Berdasarkan pembahasan yang telah dikemukakan di atas maka dapat disimpulkan bahwa kendala-kendala yang dihadapi untuk meningkatkan pemahaman sistem akuntansi 
pegawai Badan Pengelola Keuangan Aset Daerah Provinsi merupakan kendala yang berasal dari adanya perubahan peraturan perundang-undangan sehingga pemahaman pegawai Badan Pengelola Keuangan dan Aset Daerah Provinsi Bali harus di-restart dengan jalan sosialisasi terhadap perubahan-perubahan yang terkandung pada Pergub Provinsi Bali No. 96 Tahun 2018. Kendala selanjutnya mengenai jeni laporan keuangan yang tadinya hanya empat laporan keuangan, dengan adanya perubahan peraturan ada jenis laporan tambahan selain yang dipersyaratkan oleh peraturan perundangan tersebut dengan menambahkan tiga jenis laporan baru. Kendala lainnya terkait dengan anggaran berbasis akrual yang telah ditetapkan untuk dijalankan, pencatatan pengakuan pendapatan dan pencatatan pengakuan belanja/beban serta masih adanya resistensi pegawai yang menolak perubahan.

\subsection{Evaluasi Mengatasi Kendala-Kendala untuk Meningkatkan Pemahaman Sistem} Akuntansi Pegawai Badan Pengelola Keuangan Aset Daerah Provinsi Bali dalam Rangka Meningkatkan Kinerjanya

a.Evaluasi Mengatasi Kendala dari Peraturan Perundang-Undangan.

Evaluasi terhadap kendala dari peraturan perundang-undangan bahwa terbitnya Pergub Provinsi Bali No. 96 Tahun 2018 yang merubah Pergub Provinsi Bali No. 101 Tahun 2015, yang dipemahami pegawai Badan Pengelola Keuangan dan Aset Daerah Provinsi Bali terkait dengan perubahan tersebut harus di-restart untuk mengatur kendala ini maka perlu untuk dilakukan sosialisasi terhadap perubahan yang ada. Badan Pengelola Keuangan dan Aset Daerah Provinsi Bali harus lebih intens melakukan sosialisasi atau pelatihan kepada jajaran staf dan pejabatnya serta penyesuaian perubahan dari Pergub No. 101 Tahun 2015 ke Pergub No. 96 Tahun 2018. Hal ini sesuai dengan teori dari Juma dan Onkware (2015: 834) yang menyatakan bahwa evaluasi kebijakan adalah penilaian terhadap kemampuan pemerintah dalam proses dan programnya. Termasuk dalam prosesnya adalah sosialisasi atas kebijakan yang bersangkutan. Dalam hal ini keberhasilan penerapan suatu kebijakan dipengaruhi oleh keberhasilan dari sosialisasi itu dijalankan.

b. Evaluasi Mengatasi Kendala dari Jenis Laporan Keuangan yang Ditetapkan.

Kendala dari jenis-jenis laporan keuangan yang harus disusun oleh Lembaga sebagaimana Badan Pengelola Keuangan dan Aset Daerah Provinsi Bali perlu dievaluasi untuk memecahkan kendalanya. Sebaiknya jenis laporan keuangan ditetapkan saja berupa jenisnya agar terjadi kepastian. Hal ini sesuai dengan teori dari Widjajarso (2014: 44) yang mengatakan bahwa penyederhanaan dari laporan keuangan dapat mengatasi kendala adanya berbagai jenis laporan keuangan. 
c. Evaluasi Mengatasi Kendala dari Anggaran Berbasis Akrual yang Ditetapkan.

Evaluasi terhadap kendala ini harus mengikuti international best practices dalam basis akuntansi akrual selalu diikuti oleh sistem penganggaran berbasis akrual. Hal ini sesuai dengan teori dari Juma dan Onkware (2015: 834) yang menyatakan evaluasi kebijakan adalah penilaian terhadap kemampuan pemerintah dalam proses dan programnya. Dalam hal ini penerapan sistem akuntansi berbasis akrual merupakan program pemerintah.

d. Evaluasi Mengatasi Kendala dari Pengakuan Pendapatan.

Evaluasi terhadap kendala dari pengakuan pendapatan yang menurut SAPD berbasis akrual pendapatan diakui saat timbul hak dari pemerintah. Hal ini bertentangan dengan sistem pemungutan pajak yang menganut sistem self assesment yang masih memungkinkan pendapatan tersebut bisa saja berubah karena adanya restitusi pajak. Sehingga bisa saja pendapatan yang telah diakui tersebut berubah. Hal ini sesuai dengan teori Fakhrurazi (2014: 70) yang menyebutkan pemerintah nantinya harus menciptakan kriteria yang jelas atas pengakuan pendapatan tersebut. Dengan demikian, pendapatan pajak yang harus diakui adalah jika dapat diukur dan tersedia untuk operasi entitas pelaporan.

e. Evaluasi Mengatasi Kendala dari Pengakuan Belanja/Beban.

Evaluasi terhadap kendala dari pengakuan belanja beban Pemprov Bali harus menetapkan secara konsisten penggunaan istilah belanja, mengingat pengertian biaya atau beban dalam SAPD berbasis akrual artinya juga sama dengan belanja. Hal ini sesuai dengan teori Fakhrurazi (2014: 66) yang menyatakan terminologi belanja sudah tepat dan hal ini juga sesuai dengan peraturan perundangan yang berkaitan dengan anggaran pendapatan dan belanja negara.

f. Evaluasi Mengatasi Kendala dari Resistensi Pegawai.

Evaluasi terhadap kendala dari resistensi pegawai yang menunjukkan ada pegawai yang menunjukkan sikap resistensi karena pegawai ini sudah terbiasa dengan sistem yang lama. Resistensi ini dicoba untuk ditularkan pada pegawai yang menerima perubahan. Hal inilah yang menjadi kendala bagi berhasilnya perubahan. Hal ini sesuai dengan teori Robbins (2015: 126) yang menyatakan sikap yang terlihat dalam perubahan peraturan atau kebijakan pada pemerintahan dapat digunakan untuk mendeteksi kecenderungan seseorang. Individu dapat memiliki sikap positif atau negatif terhadap suatu perubahan. Sikap positif yang ditunjukkan pada perubahan peraturan pemerintah yang baru terlihat apabila aparatur pemerintah daerah mengembangkan potensinya. Sebaliknya, sikap negatif terhadap perubahan peraturan pemerintah yang baru dilatarbelakangi oleh 
aparatur pemerintah daerah yang kurang memiliki kemauan untuk mengembangkan dirinya demi mendukung kemajuan organisasi itu sendiri. Bagi individu yang memiliki sumber daya manusia berkualitas maka akan menyambut perubahan peraturan pemerintah dengan semangat baru dan optimisme. Perubahan peraturan pemerintah ataupun perubahan kebijakan akan memberi kesempatan pada individu untuk mengembangkan kreativitas, meningkatkan potensi, dan tantangan untuk memajukan daerah.

Berdasarkan pembahasan yang telah dikemukakan di atas maka dapat disimpulkan bahwa evaluasi untuk mengetahui kendala-kendala untuk meningkatkan pemahaman akuntansi diharapkan agar kinerja pegawai di Badan Pengelola Keuangan dan Aset Daerah Provinsi Bali dapat meningkatkan kinerja pegawai meliputi evaluasi terhadap kendala dari adanya perubahan peraturan perundang-undangan dilakukan sosialisasi yang lebih intens terhadap perubahan yang ada, evaluasi dari kendala jenis-jenis laporan keuangan sebaiknya jenis laporan keuangan ditetapkan saja berupa jenisnya agar terjadi kepastian dan evaluasi untuk mengatasi kendala terkait dengan anggaran berbasis akrual yang telah ditetapkan untuk dijalankan, pencatatan pengakuan pendapatan dan pencatatan pengakuan belanja/beban harus dilakukan sesuai tuntutan peraturan perundang-undangan yang baru.

\section{PENUTUP}

\subsection{Kesimpulan}

1. Sistem akuntansi pada Badan Pengelola Keuangan Aset Daerah Provinsi Bali adalah sistem atau Standar Akuntansi Pemerintahan Daerah (SAPD) yang berbasis IT system. Sistem ini memberi manfaat pada peningkatan kualitas pelaporan keuangan di Provinsi Bali. Untuk menggunakan sistem tersebut diperlukan komitmen tidak hanya dari pimpinan Badan Pengelola Keuangan dan Aset Daerah Provinsi Bali saja, tapi juga dari Gubernur Bali. (SAPD) yang digunakan ini berbasis IT system sehingga diperlukan SDM yang memiliki kompetensi tinggi tidak saja di bidang akuntansi, namun terlebih-lebih di bidang IT.

2. Kendala-kendala yang dihadapi untuk meningkatkan pemahaman sistem akuntansi pegawai Badan Pengelola Keuangan Aset Daerah Provinsi merupakan kendala yang berasal dari adanya perubahan peraturan perundang-undangan, kendala mengenai jeni 
laporan keuangan yang tadinya hanya empat laporan keuangan ditambah dengan tiga jenis laporan baru. Kendala lainnya terkait dengan anggaran berbasis akrual, pencatatan pengakuan pendapatan dan pencatatan pengakuan belanja/beban serta masih adanya resistensi pegawai yang menolak perubahan.

3. Evaluasi untuk mengetahui kendala-kendala untuk meningkatkan pemahaman akuntansi diharapkan agar kinerja pegawai di Badan Pengelola Keuangan dan Aset Daerah Provinsi Bali dapat meningkatkan kinerja pegawai meliputi evaluasi terhadap kendala dari adanya perubahan peraturan perundang-undangan dilakukan sosialisasi yang lebih intens, evaluasi dari kendala jenis-jenis laporan keuangan sebaiknya jenis laporan keuangan ditetapkan saja berupa jenisnya agar terjadi kepastian, evaluasi dari kendala terkait dengan anggaran berbasis akrual, pencatatan pengakuan pendapatan dan pencatatan pengakuan belanja/beban harus dilakukan sesuai tuntutan peraturan perundang-undangan yang baru.

\subsection{Saran}

1. Bagi Pemerintah Provinsi Bali dan Badan Pengelola Keuangan dan Aset Daerah Provinsi Bali disarankan untuk menyesuaikan kebijakan akuntansi dan sistem akuntansi dalam Pergub Provinsi Bali No. 96 Tahun 2018 dengan Peraturan Pemerintah Nomor 71 Tahun 2010 tentang Standar Akuntansi Pemerintahan dan Peraturan Menteri Dalam Negeri Nomor 64 Tahun 2013 tentang Penerapan Sistem Akutansi Pemerintah Berbasis Akrual pada Pemerintahan Daerah.

2. Bagi Badan Pengelola Keuangan dan Aset Daerah Provinsi Bali disarankan untuk meningkatkan pemahaman para pengelola keuangan Pemprov Bali akan standar akuntansi pemerintahan daerah, misalnya sosialisasi berupa seminar atau diskusi dengan aparat pemerintah, serta dilakukan training atau pelatihan berkaitan dengan standar akuntansi pemerintahan berbasis akrual tersebut.

3. Bagi Badan Pengelola Keuangan dan Aset Daerah Provinsi Bali perlunya perekrutan pegawai yang memiliki keahlian di bidang akuntansi daerah sekaligus yang menguasai IT untuk mengelola keuangan daerah agar pencatatan dan pelaporan keuangan Pemprov Bali dapat terlaksana dengan baik. 


\section{DAFTAR PUSTAKA}

\section{Sumber Buku}

Fakhrurazi. 2014. Standar Akuntansi Pemerintahan. Bandung: Remaja Rosdakarya.

Robbins, Stephen P. 2015. Organizational Behavior, Concept Contropversies and Applications, Prentice Hall Inc. USA. Terjemahan. Jakarta: P.T. Indeks Kelompok Gramedia.

Satmoko, Nofan. 2015. Penerapan Akuntansi Berbasis Akrual Dalam Sistem Akuntansi Pemerintah dan Sektor Publik. Yogyakarta: Andi Offset.

Sinaga, Jamason. 2015. Selamat Datang Standar Akuntansi pemerintahan. Jakarta: Gramedia Pustaka Utama.

Wajong J. 2015. Administrasi Keuangan Daerah. Jakarta: Penerbit Balai Buku Ichtiar.

Widjajarso, Bambang. 2009. Penerapan Basis Akrual pada Akuntansi Pemerintah Indonesia: Sebuah Kajian Pendahuluan. Jakarta: Raja Grafindo Persada.

\section{Sumber Jurnal / Artikel /Tesis}

Juma, Thomas Otieno dan Onkware, Ken. 2015. "The Challenges of Public Policy Formulation and Evaluation". International Journal of Economics, Commerce and Management. Vol. III, Issue 11.

Wijaya, Henryanto. 2014. "Standar Akuntansi Pemerintahan (PP No. 24 Tahun 2005) untuk Pengelolaan Keuangan Negara yang Transparan dan Akuntabel". Jurnal Akuntansi, Vol.XII, No.3.

\section{Sumber Peraturan Perundang-Undangan}

Peraturan Menteri Dalam Negeri Nomor 59 Tahun 2007 tentang Perubahan Atas Peraturan Menteri Dalam Negeri Nomor 13 Tahun 2006 tentang Pedoman Pengelolaan Keuangan Daerah.

Peraturan Menteri Dalam Negeri Nomor 64 Tahun 2013 tentang Penerapan Sistem Akutansi Pemerintah Berbasis Akrual pada Pemerintahan Daerah.

Peraturan Pemerintah Nomor 71 Tahun 2010 tentang Standar Akuntansi Pemerintahan.

Peraturan Daerah Provinsi Bali Nomor 8 Tahun 2014 tentang Pokok-Pokok Pengelolaan Keuangan Daerah.

Peraturan Gubernur Bali Nomor 101 Tahun 2015 tentang Kebijakan Akuntansi ProvinsiBali. 